水文・水資源学会誌

J. Japan Soc. Hydrol. \& Water Resour.

\begin{tabular}{ll} 
Vol. 8. No.1 (1995) & pp. $49-56$ \\
\hline
\end{tabular}

\title{
Estimation of Spatial Soil Water Distribution and Deep Percolation under Sprinkler Irrigation
}

\author{
散水潅溉における土壌水分の空間的分布と深層損失の推定
}

\author{
Jiusheng $\mathrm{LI}^{*}$ \\ (United Graduate School of Agricultural Science, Ehime University) \\ 李 久生 \\ (愛媛大学大学院連合農学研究科) \\ Hiroshi KAWANO** (Faculty of Agriculture, Kagawa University) \\ 河野 広 \\ (香川大学農学部)
}

\begin{abstract}
An approximate model for simulating infiltration under sprinkler irrigation was developed. The model, which took account of the nonuniformity of both water application and initial soil water content, was verified by field experiments and then was used to study the spatial soil water distribution under sprinkler irrigation. It was found that the effect of water application uniformity on the uniformity of soil water content is not important for the studied sandy soil. The influence of water application uniformity on deep percolation was also examined and showed that deep percolation decreases significantly as water application uniformity increases for the uniformity less than $85 \%$, however, increasing water application uniformity becomes ineffective for decreasing deep percolation when the uniformity exceeds $85 \%$.
\end{abstract}

Key words: Uniformity, Soil water content, Deep percolation, Sprinkler irrigation.

散水潅測における浸透を近似的に推定するモデルを開発した。このモデルは散水量分布と初期土淁水分量分布の不均一性を考慮 している.モデルは围場実験結果で実証したのち、シミュレーションに用いた。 その結果, 土鎄水分の均等性に及惊す散水量の均等 性の影䉕は供試土壌においては重要でないことが判った。また, 散水量の均等性が $85 \%$ 以下の範囲では, 散水量の均等性の増大に 伴って深層損失が明確に低下することが判った，しかし，85\%以上ではその効果はほとんど無い.

キーワード：均等性, 土壤水分, 深層浸透, 散水潅僦

\section{I . INTRODUCTION}

Water uptake by plant, and thus crop yield, is affected more directly by the soil water distribution than by the surface-measured water application from sprinklers; however, there is much less research on the former than on the latter. The apparent, difference between sprinkler irrigation and natural rainfall is that sprinkler irrigation always exhibits some de- gree of nonuniformity. Considering the nonuniformity of water application, Hart (1972) studied the subsurface soil water distribution under sprinkler irrigation by using a dynamic model, but did not take account of the nonuniform characteristics of initial soil water distribution. Meanwhile, no experiment accompanied his simulation to verify his model.

Excessive deep percolation might not only decrease the utilizing efficiency of the irrigation

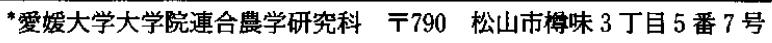

United Grad. School of Agric. Sci., Ehime Univ., 3-5-7, Tarumi, Matsuyama, Ehime, 790, Japan

**香川大学農学部農業工学科 $=761-07$ 香川県木田郡三木町

Faculty of Agric., Kagawa Univ., Miki-Cho, Kagawa-ken, 761-07, Japan 
water but also cause the contamination of ground water; so the estimation of deep percolation has been a subject of interest to many researchers (Ben-Asher and Ayars, 1990; Rice et al., 1986; Russo, 1985; and Warrick et al , 1989).

The objective of this study was to develop and verify an approximate model, which included both the nonuniformity of water application and of initial soil water distribution, for evaluating the effect of water application uniformity on soil water distribution and for quantifying the relationship between deep percolation and water application uniformity .

\section{II . MODEL DESCRIPTION}

Accurately speaking, infiltration under sprinkler irrigation should be two- or three-dimensional water movement in the soil. However, if the area controlled by sprinklers is divided into many small grids, such as $2 \mathrm{~m} \times 2 \mathrm{~m}$ in field experiments of this study, infiltration for each grid may be approximately considered as a one-dimensional water movement, since the unit area has a characteristic dimension $(2 \mathrm{~m})$ considerably larger than the depth of wetted zone and the variation of application rates over this unit area may be neglected. Assuming a homogeneous and semi-infinite soil, and neglecting the evaporation during the process of an irrigation, infiltration for each grid may be expressed as (Kutilek et al., 1991):

$$
\begin{aligned}
& \frac{\partial \theta}{\partial t}=\frac{\partial}{\partial z}\left[D(\theta) \frac{\partial \theta}{\partial z}\right]-\frac{\partial K(\theta)}{\partial z} \\
& \theta=\theta_{i a}(z) \quad t=0, \quad z \geq 0 \\
& \theta=\theta_{i a}(z) \quad t>0, \quad z \rightarrow \infty \\
& -D(\theta) \frac{\partial \theta}{\partial z}+K(\theta)=A R_{i} \quad z=0, t>0
\end{aligned}
$$

where $z=$ vertical coordinate which is considered to be positive downward (m); $\theta=$ volumetric soil water content $\left(\mathrm{cm}^{3} / \mathrm{cm}^{3}\right) ; K=$ hydraulic conductivity $(\mathrm{m} / \mathrm{s}) ; D=$ hydraulic diffusivity $\left(\mathrm{m}^{2} / \mathrm{s}\right) ; t=$ time (s); $\theta_{i a}=$ initial soil water content for the ith grid $\left(\mathrm{cm}^{3} / \mathrm{cm}^{3}\right)$; and $A R_{i}=$ water application rate for the ith grid $(\mathrm{m} / \mathrm{s})$.
Eq. 1 accompanied with the initial and boundary conditions presented by Eqs. $2-4$ can be solved by using a finite difference method.

By completing infiltration simulation for all the grids, then Christiansen uniformity coefficient of soil water within the wetted zone, $C U_{s}$, is computed by:

$$
\begin{aligned}
C U_{s} & =\left[1-\sum_{i=1}^{N}\left|W_{i}-\bar{W}\right| /(N \bar{W})\right] \\
& \times 100 \\
W_{i} & =\int_{0}^{W z} \theta_{i}(z) d z \\
\bar{W} & =\left(\sum_{i=1}^{N} W_{i}\right) / N
\end{aligned}
$$

where $\theta_{i}(z)=$ soil water content at depth $z$ for the ith grid $\left(\mathrm{cm}^{3} / \mathrm{cm}^{3}\right) ; W_{i}=$ quantity of profile water within the wetted zone for the ith grid; $\bar{W}=$ mean quantity of profile water; $N=$ number of grids; and $W Z=$ depth of wetted zone $(\mathrm{cm})$ (assumed to be $30 \mathrm{~cm}$ in this study).

The mean soil water content within the wetted zone over the irrigated area can be determined by:

$$
\theta=\bar{W} / W Z
$$

In simulation, the irrigation depth is determined according to initial soil water deficit and can be expressed as:

$$
M=10\left(\beta_{2}-\beta_{1}\right) W Z
$$

where $M=$ irrigation depth $(\mathrm{mm}) ; \beta_{1}=$ initial mean soil water content within the wetted zone $\left(\mathrm{cm}^{3} / \mathrm{cm}^{3}\right)$; and $\beta_{2}=$ upper limitation of soil water content for irrigation $\left(\mathrm{cm}^{3} / \mathrm{cm}^{3}\right)$, normally less than field capacity (FC).

\section{VERIFICATION OF THE MODEL}

\section{Field Experiments}

Field experiments were conducted on a sandy soil with the dry bulk density $1.20 \mathrm{~g} / \mathrm{cm}^{3}$, field capacity $0.37 \mathrm{~cm}^{3} / \mathrm{cm}^{3}$, and saturated water content $0.40 \mathrm{~cm}^{3} / \mathrm{cm}^{1}$. Four impact sprinklers with $2.9 \mathrm{~mm}$ square nozzles and one-meter-height risers were arranged in $6 \mathrm{~m} \times 14 \mathrm{~m}$ rectangular pattern for applying water. The area limited by four sprinklers was divided into 21 equal square grids with the area of $2 \mathrm{~m} \times 2 \mathrm{~m}$. A catch can with 15 $\mathrm{cm}$ inside diameter was placed at the center of 
each grid to measure distribution of water application. As usual, Christiansen uniformity coefficient $\left(C U_{w}\right)$, which is given in Eq. 10, is used to evaluate the uniformity of water application:

$$
C U_{w}=\left[1-\sum_{i=1}^{N}\left|x_{i}-\bar{x}\right| /(N \bar{x})\right] \times 100 \quad \text { (10) }
$$

where $x_{i}=$ water application depth of the ith catch-can; and $\bar{x}=$ the mean of all $N$ observations.

Soil water content was measured by the gravimetric method and sampled downward to 30 or $50 \mathrm{~cm}$ depending upon the assigned application depth and the initial soil water deficit. Initial soil water profile for each grid was measured before the beginning of irrigation. After an assigned quantity of water was applied, soil water content profile for each grid was measured again (usually $1800 \mathrm{~s}$ later, this redistribution period was treated as $A R_{i}=0$ in the following verification of the model). Five infiltration experiments were conducted with the uniformity of water application $\left(C U_{w}\right)$ ranging from 53 to $72 \%$ and irrigation depths (M) ranging from $6.7 \mathrm{~mm}$ to 17.0

\section{Water content, $\mathrm{cm}^{3} / \mathrm{cm}^{3}$}

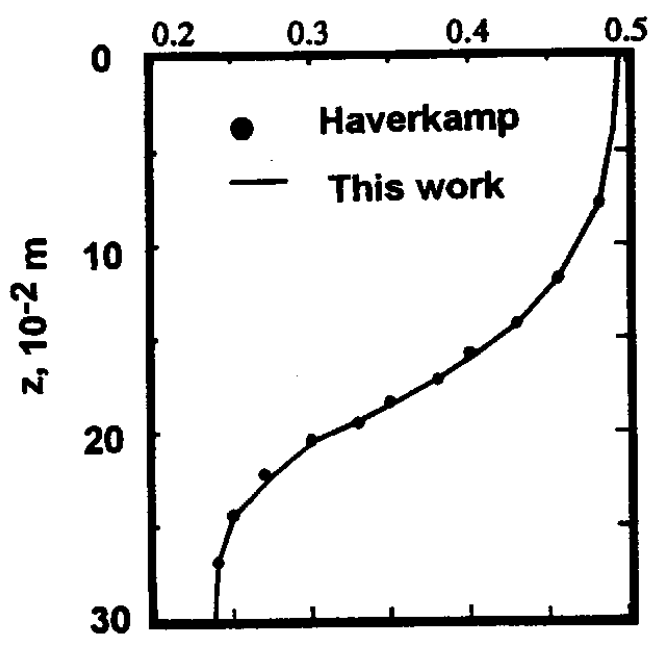

Fig. 1 A comparison between Haverkamp et al. (1977, Table 3) numerical results and the computational soil water profile of this work (Yolo light clay, $A R_{\mathrm{i}}$ $=1.22 \times 10^{-7} \mathrm{~m} / \mathrm{s}, t=100,080 \mathrm{~s}$ ) mm (Table 1) .

\section{Verification}

First, the validity of the program for simulating a one-dimensional infiltration under a constant application rate was verified by comparing the computational soil water profile of this study with of Haverkamp et al. (1977). There is an excellent agreement between them (Fig. 1). Then the program was run for each grid. The soil moisture characteristic curve (Fig. 2) and saturated hydraulic conductivity, $K_{s}\left(K_{s}=2 \times 10^{-5} \mathrm{~m} / \mathrm{s}\right)$, for the tested soil were

Table 1 A summary of water application performances for infiltration experiments and initial mean soil water content $(\theta)$ and uniformity coefficient within the wetted zone $\left(C U_{s}\right)$

\begin{tabular}{c|c|c|c|c|c}
\hline Exp. No. & $\begin{array}{c}A R \\
(\mathrm{~mm} / \mathrm{h})\end{array}$ & $\begin{array}{c}M \\
(\mathrm{~mm})\end{array}$ & $\begin{array}{c}C U_{\mathrm{w}} \\
(\%)\end{array}$ & $\begin{array}{c}\theta \\
\left(\mathrm{cm}^{3} / \mathrm{cm}^{3}\right)\end{array}$ & $\begin{array}{c}C U_{\mathrm{s}} \\
(\%)\end{array}$ \\
\hline 1 & 14.9 & 10.0 & 53 & 0.29 & 96 \\
2 & 11.3 & 13.2 & 60 & 0.32 & 94 \\
3 & 12.2 & 6.7 & 61 & 0.25 & 92 \\
4 & 11.5 & 17.0 & 69 & 0.34 & 92 \\
5 & 12.0 & 12.0 & 72 & 0.29 & 91 \\
\hline
\end{tabular}

$A R=$ mean water application rate, $1 \mathrm{~mm} / \mathrm{h}=2.78 \times 10^{-7} \mathrm{~m} / \mathrm{s}$.

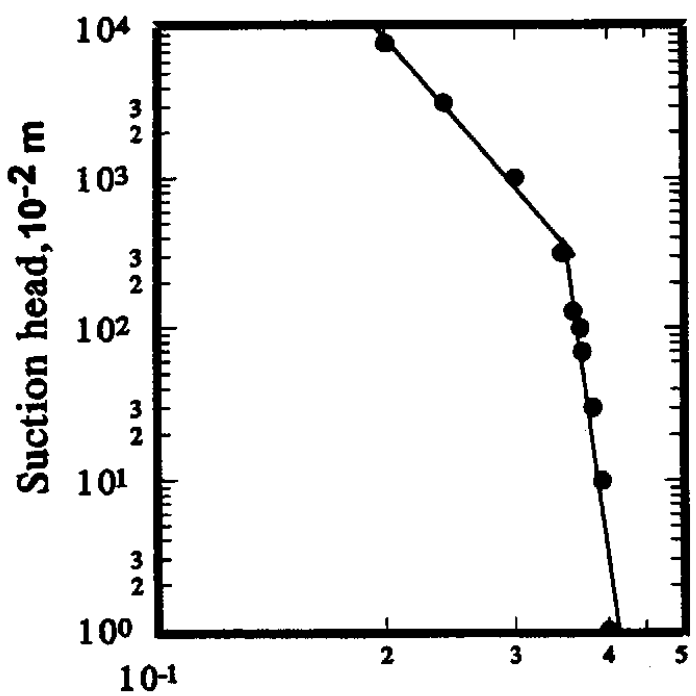

Water content, $\mathrm{cm}^{3} / \mathrm{cm}^{3}$

Fig. 2 Soil moisture characteristic curve 
determined experimentally. For the purpose of simulation, the soil moisture characteristic curve was correlated as :

$$
\begin{array}{lll}
H=1.66\left(\theta / \theta_{s}\right)^{-5.70} & \theta \leqq 0.35 & \text { (11a) } \\
H=0.09\left(\theta / \theta_{s}\right)^{-27.21} & \theta>0.35 & \text { (11b) }
\end{array}
$$

where $\mathrm{H}=$ the absolute value of soil suction pressure head $(\mathrm{m})$; and $\theta_{s}=$ saturated soil water content $\left(\mathrm{cm}^{3} / \mathrm{cm}^{3}\right)$.

The hydraulic conductivity $K(\theta)$ was determined by Jackson's formulation (Hillel, 1980):

$$
\begin{aligned}
K_{i}= & K_{s}\left(\theta_{i} / \theta_{s}\right) \sum_{j=i}^{m}\left[(2 j+1-2 i) H_{j}^{-2}\right] / \\
& \sum_{j=i}^{m}\left[(2 j-1) H_{j}^{-2}\right]
\end{aligned}
$$

where $K_{i}=$ hydraulic conductivity at a soil water content $\theta_{i} ; \mathrm{m}=$ number of increment of $\theta$ (equal intervals from dryness to saturation); $H_{i}=$ absolute suction head at the midpoint of each $\theta$ increment; $j$ and $i=$ summation indices; and $C=$ an arbitrary constant, is assigned as a unit value in this study according to Kunze et al . and Jackson' works (Hillel, 1980).

The relationship between $K(\theta)$ and $\theta$ might be correlated as:

$$
K(\theta)=8.33 \times 10^{-7}\left(\theta / \theta_{s}\right)^{16.37} \quad \theta \leqq 0.35
$$

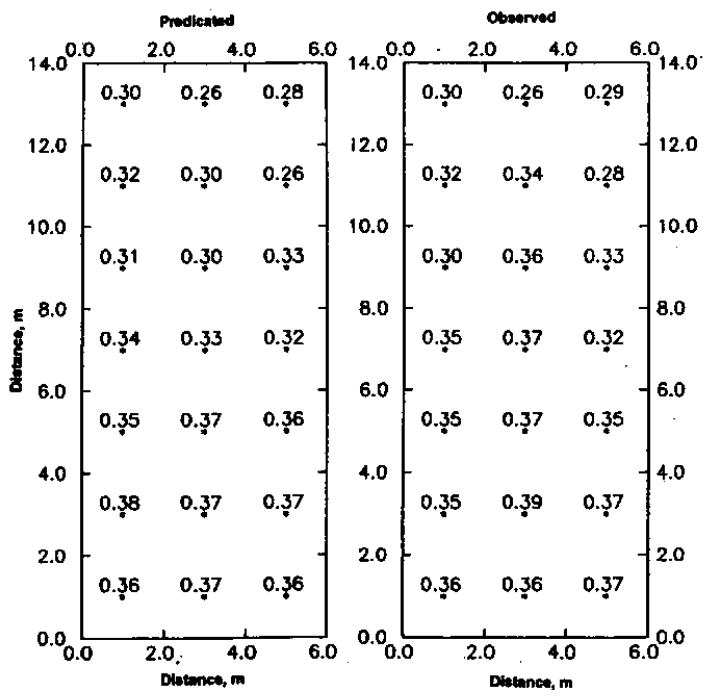

Fig. 3 Predicted and observed scatters of soil water contents at the depth of 0.075 to $0.125 \mathrm{~m}$ for Exp. No. 1

$$
K(\theta)=1.33 \times 10^{-5}\left(\theta / \theta_{s}\right)^{42.08} \quad \theta>0.35
$$

It should be noted that the segmental functions of $K(\theta)$ (Eq. 13) have discontinuity at $\theta=0.35$. This discontinuity is due to the segmental regression error and may cause some small simulation errors while $\theta$ is slightly greater than 0.35 (from 0.350 to 0.356 ).

The hydraulic diffusivity function $D(\theta)$ can be derived from $K(\theta)$ and the soil moisture characteristic curve by:

$$
D(\theta)=K(\theta)(d H / d \theta)
$$

As an example, Fig. 3 illustrates the predicated and the observed scatters of soil water contents at the depth of 7.5 to $12.5 \mathrm{~cm}$ for Exp. No. 1. Table 2 presents a comparison between the predicted values of mean soil water contents as well as uniformity coefficients of soil water and the observed ones for all five experiments. From Fig. 3 as well as Table 2, it can be seen that there is a good agreement between the predicated and the observed values. Thus, one can conclude that the foregoing model can be used for estimating the spatial distribution of soil water under nonuniform water application.

Table 2 A comparison between the predicted and the observed mean soil water contents as well as uniformity coefficients of soil water content at the depth of 0.075 to $0.125 \mathrm{~m}$

\begin{tabular}{c|c|c|c|c}
\hline \multirow{2}{*}{ Exp. No. } & \multicolumn{2}{|c|}{ Predicted } & \multicolumn{2}{c}{ Observed } \\
\cline { 2 - 5 } & $\begin{array}{c}\theta \\
\left(\mathrm{cm}^{3} / \mathrm{cm}^{3}\right)\end{array}$ & $\begin{array}{c}C U_{\mathrm{s}} \\
(\%)\end{array}$ & $\begin{array}{c}\theta \\
\left(\mathrm{cm}^{3} / \mathrm{cm}^{3}\right)\end{array}$ & $\begin{array}{c}C U_{\mathrm{s}} \\
(\%)\end{array}$ \\
\hline 1 & 0.33 & 91 & 0.34 & 92 \\
2 & 0.36 & 96 & 0.35 & 94 \\
3 & 0.33 & 94 & 0.30 & 91 \\
4 & 0.38 & 98 & 0.38 & 94 \\
5 & 0.37 & 94 & 0.35 & 93 \\
\hline
\end{tabular}




\section{IV . RESULTS AND DISCUSSION}

1. Selection of Initial and Boundary Conditions

(1) Initial soil water content and its distribution

The observed initial mean soil water contents ( $\theta$, see Eq. 8) and uniformity coefficients within the wetted zone ( $C U_{s}$, see Eq. 5) are presented in Table 1. It can be seen that all of the initial soil water uniformity coefficients are larger than $90 \%$. Three typical soil water distribution scatters, Exp. No. 1, 3 and 5, were therefore selected as initial conditions in the following simulations. The initial mean soil water content of Exp. No. 3 corresponds to $0.7 \mathrm{FC}$, and the initial water contents of Exp. No. 1 and 5 correspond to $0.8 \mathrm{FC}$.

\section{(2) Water application}

Scatters of water application were based on the measured overlapped data in this study for uniformity coefficients $\left(C U_{w}\right)$ ranging from 53 to $72 \%$, on the authors' previous experimental data (unpublished) for $C U_{w}$ ranging from 86 to $89 \%$, and on a rainfall event for $C U_{w}$ of $98 \%$. The mean application rate for all water application data used in the following simulations ranged from 12.0 to $14.9 \mathrm{~mm} / \mathrm{h}\left(3.33 \times 10^{-6}\right.$ to $4.14 \times 10^{-6}$

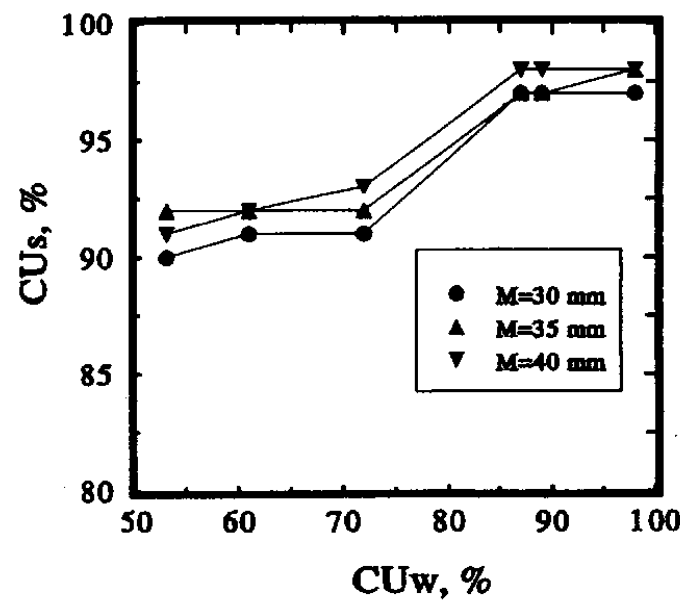

Fig. 4 Relationship between soil water uniformity within the wetted zone and water application uniformity $\mathrm{m} / \mathrm{s})$

\section{Relationship between Spatial Soil Water \\ Distribution and Water Application Uni- formity}

Fig. 4 shows the uniformity coefficient of soil water within the wetted zone $\left(C U_{s}\right)$ as a function of water application uniformity coefficient $\left(C U_{w}\right)$ for several irrigation depths. In simulation, $\beta_{1}$ value is $0.25 \mathrm{~cm}^{3} / \mathrm{cm}^{3}$ which corresponds to $0.7 \mathrm{FC}$. Irrigation depths of 30,35 and $40 \mathrm{~mm}$ correspond to $\beta_{2}$ values of $0.95 \mathrm{FC}, 1.00 \mathrm{FC}$ and $1.05 \mathrm{FC}$, respectively. It indicates that $C U_{s}$ increases slightly with $C U_{w}$, and a larger irrigation depth results in a slightly higher $C U_{s}$ for a given $C U_{w}$. Fig. 5 shows the effect of initial soil water content on $C U_{\mathrm{s}}$. In this simulation, the initial $C U_{s}$ value for $\beta_{1}=0.7 \mathrm{FC}(92 \%)$ is quite same as for $\beta_{1}=0.8 \mathrm{FC}(91 \%)$. As illustrated in Fig. 5, the initial soil water content has no sig. nificant effect on the spatial soil water distribution.

Both Fig. 4 and Fig. 5 indicate that the influence of water application uniformity, $C U_{w}$, on the $C U_{s}$ value is not important. Even at a very low water application uniformity of $53 \%$, for example, the uniformity of soil water still exceeds $90 \%$ after a certain quantity of irrigation

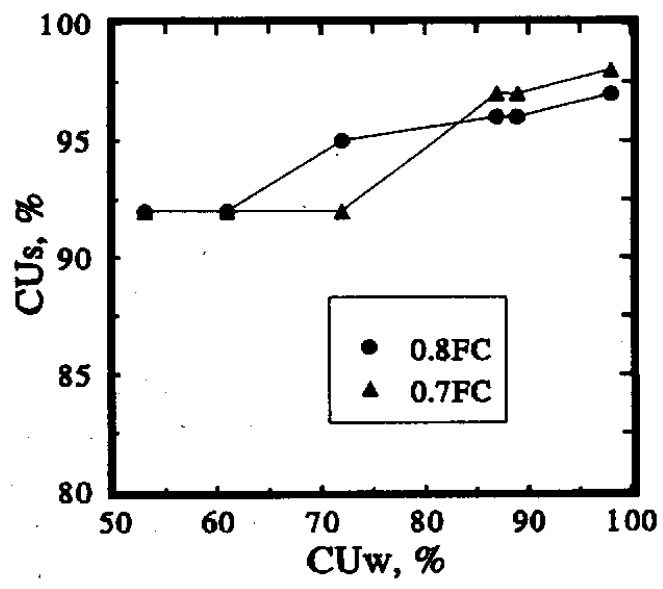

Fig. 5 Effect of initial soil water content on the uniformity of soil water content with in the wetted zone 
water is applied. This is a high value striven for in many commercial installations. It could be inferred from the above that water uptake by plant, and thus crop yield, appears not to be closely related to water application uniformity. The experimental results of Davis (1963) is helpful for understanding this result. He observed that for measured $C U_{w}$ of $87.2,86.8,63.0$ and $16.0 \%$, the resulting yields of alfalfa were 8.04 , $8.12,8.12$ and 7.54 tons per acre, respectively. It is clear that $C U_{w}$ is not a good indicator of crop yield.

\section{Relationship between Deep Percolation and Water application Uniformity}

Several researchers have estimated deep percolation by different methods (Rice et al., 1986; and Russo, 1985). Ben-Asher and Ayars (1990) studied the effect of irrigation nonuniformity on deep percolation by the principle of water balance. Warrick et al . (1989) determined deep percolation by distribution functions of water application but did not consider the effect of nonuniformity of initial soil water contents and soil water downward movement. Practically, even if irrigation quantity does not exceed field capacity, a fraction of the irrigation water may still percolate out of the wetted zone by gravity. The relative deep percolation percentage, $D P$, is defined as:

$$
\begin{aligned}
D P= & \left(1-\left\{\sum_{i=1}^{N} \int_{0}^{W Z}\left[\theta_{i}(z)-\theta_{i a}(z)\right] d z\right\}\right. \\
& /(M N)) \times 100
\end{aligned}
$$

In order to determine the relative deep percolation percentage, $D P$, the simulation was run until an assigned quantity of water was applied. Fig. 6 illustrates the relationship between $D P$ and $C U_{w}$ for a given initial soil water content $\left(\beta_{1}=0.7 \mathrm{FC}\right)$ under several irrigation depths. It indicates that $D P$ decreases significantly as $C U_{w}$ increases while $C U_{w}$ is less than $85 \%$ for a given irrigation depth, however, $D P$ remains almost the constant when $C U_{w}$ exceeds $85 \%$. The significant influence of irrigation depth on deep percolation is also seen in the fig. ure. At a given water application uniformity, larger irrigation depth leads to a considerably larger quantity of deep percolation. For a $72 \%$ water application uniformity, for example, the relative deep percolation percentage is $8 \%$ for a $30 \mathrm{~mm}$ irrigation, $13 \%$ for a $35 \mathrm{~mm}$ irrigation, whereas it reaches up to $24 \%$ for a $40 \mathrm{~mm}$ irrigation.

Fig. 7 illustrates the effect of initial soil water content on the $D P$ and $C U_{w}$ relation. Initial soil water uniformity in this simulation is $92 \%$ for $\beta_{1}$ $=0.7 \mathrm{FC}(M=33 \mathrm{~mm})$ and $91 \%$ for $\beta_{1}=0.8 \mathrm{FC}$ $(M=22 \mathrm{~mm})$. At a given water application uniformity, $\beta_{1}$ values of $0.7 \mathrm{FC}$ and $0.8 \mathrm{FC}$ resulted in almost the same $D P$ value.

Both Fig. 6 and Fig. 7 indicate that increasing water application uniformity is ineffective for decreasing deep percolation when the uniformity exceeds $85 \%$.

Fig. 8 illustrates the effect of initial soil water uniformity coefficient on deep percolation. The initial soil water content for this simulation is 0.8 FC $(M=22 \mathrm{~mm})$. It is clear that a lower initial soil water uniformity results in a considerably larger quantity of deep percolation for any $C U_{w}$ value, especially when $C U_{w}$ is less than $85 \%$.

\section{SUMMARY AND CONCLUSIONS}

Infiltration under nonuniform water applications should be accurately described by threedimensional water movement in the soil. By dividing the area controlled by sprinklers into many small sub-areas and assuming the infiltration for each sub-area to be one-dimensional, an approximately model for simulating infiltration under sprinkler irrigation was developed. The verifications by field experiments demonstrated that the above assumption was practically acceptable. Hart (1972) also showed that the lateral movement of water within the soil under nonuniform sprinkler irrigation was negligible. The model was used to estimate the relationship between uniformity of soil water content and water application uniformity. It was found that the effect of water 


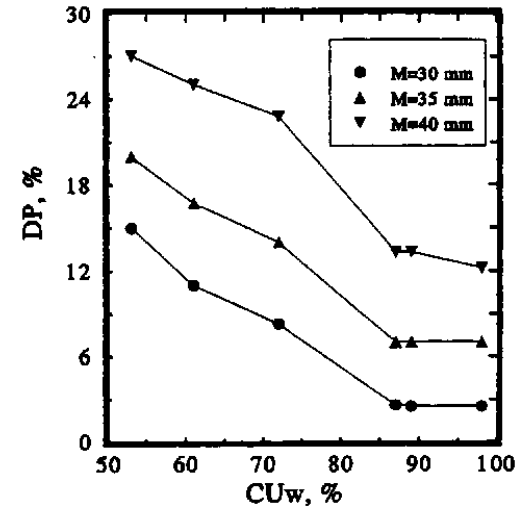

Fig. 6 Relationship between relative deep percolation percentage and water application uniformity

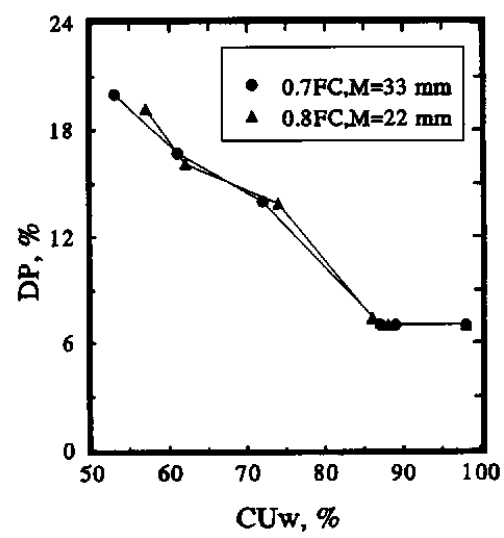

Fig. 7 Effect of the initial soil water content on the relative deep percolation percentage and water application uniformity relation

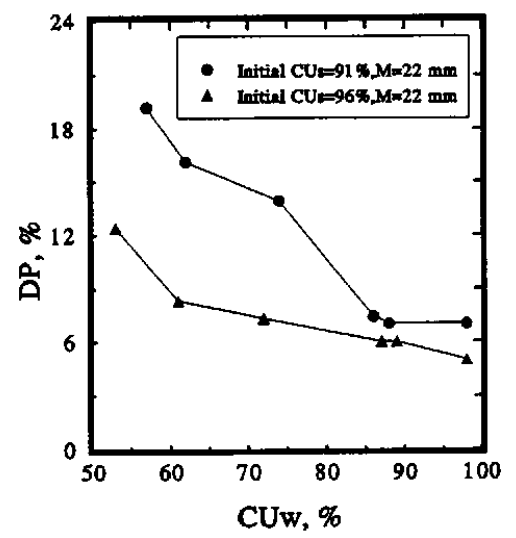

Fig. 8 Effect of the initial uniformity of soil water content on the relative deep percolation percentage and water application uniformity relation application uniformity on the spatial soil water distribution is not as important as it was supposed. The influence of water application uniformity on deep percolation was also examined by simulation and showed that deep percolation decreased significantly with increasing water application uniformity for the uniformity less than $85 \%$, however, increasing water application uniformity became ineffective for decreasing deep percolation when the uniformity exceeded $85 \%$. For a given water application uniformity, deep percolation mainly depends on irrigation quantity. The conclusions drawn from this study would be useful for formulating design criterion for sprinkler irrigation uniformity. Meanwhile, these conclusions tends to be safe for practical purposes because the lateral movement of water within the soil was neglected.

\section{REFERENCES}

1) Ben-Asher, J. and J. E. Ayars. 1990. Deep seepage under nonuniform irrigation, I. Theory. J. Irrig. and Drain. Engrg., ASCE. 116 (3): 354-363.

2) Davis, J. R. 1963. Efficiency factors in sprinkler system design, Sprinkler Irri. Assn. Open Tech. Conf. Proc. 13-50.

3) Hart, W. E. 1972. Subsurface distribution of nonuniformly applied surface waters. Transactions of the ASAE. 15(4): 656-661, 666.

4) Haverkamp, R., M. Vauclin, J. Touma, P. J. Wierenga and G. Vachaud. 1977. A comparison of numerical simulation models for one-dimensional infiltration. Soil Sci. Soc. Am. J. 41: 285-294.

5 ) Hillel, D. 1980. Fundamentals of soil physics. Academic Press, A subsidiary of Harcourt Brace Jovanovich, Publisher.

6) Kutilek, M., K. Zayani, R. Haverkamp, J. Y. Parlange and G. Vachaud. 1991. Scaling of the Richards equation under invariant flux boundary conditions. Water Res. Res. 28 (9) : 2181-2185.

7) Rice, R. C., R. S. Bowman and D. B. 
Jaynes. 1986. Percolation of water below irrigated fields. Soil Soc. Am. J. 50: 855859.

8) Russo, D. 1985. Leaching and water requirement studies in a gypsiferous desert soil. Soil Sci. Soc. Am. J. 49: 432-437.
9) Warrick, A. W., W. E. Hart and M. Yitayew. 1989. Calculation of distribution and efficiency from nonuniform irrigation. J. Irri. and Drain. Engrg., ASCE. 115 (IR4): 674-686.

(Received: Jun. 16, 1994, Accepted: Aug. 26, 1994) 